\title{
ANALYSIS OF RELIABILITY/ITEMS OF QUESTIONNAIRE IN RESEARCH OF INFLUENCING STUDENTS' ATTITUDES TOWARDS TEACHING SUBJECTS BY MULTIMEDIA TEACHING MATERIALS
}

\author{
Ján ZÁHOREC - Michal MUNK - Alena HAŠKOVÁ
}

\begin{abstract}
The contribution follows the authors' articles published in the previous JTIE issues (Záhorec - Hašková, JTIE, 1/2009, s. 83 - 91; Záhorec - Hašková, JTIE, 2/2009, s. 69 - 76) in which some results of a broader research focused on observation of possibilities to influence students ' attitudes and approaches to particular subjects, mainly those belonging to their less favourite ones, were presented. In this contribution the authors present results of an analysis of reliability/items of a questionnaire which was used within the carried out research. The analysis of reliability/items of the questionnaire was done to develop an appropriate tool to obtain reliable data to verify possibilities to influence students' approaches to the subjects through a pedagogical intervention of created electronic teaching materials and interactive animations Principles of Geometry Optics into the teaching process.
\end{abstract}

Key words: multimedia teaching material, questionnaire, reliability, analysis of reliability/items, Cronbach's alpha coefficient.

\section{ANALÝZA SPOLAHLIVOSTI/POLOŽIEK DOTAZNÍKA VÝSKUMU OVPLYVŇOVANIA VZŤAHU ŠTUDENTOV K VYUČOVACÍM PREDMETOM PROSTREDNÍCTVOM MULTIMEDIÁLNYCH UČEBNÝCH MATERIÁLOV}

\begin{abstract}
Abstrakt: Prispevok nadväzuje na články uverejnené v predchádzajúcich čislach časopisu (Záhorec Hašková, JTIE, 1/2009, s. 83 - 91; Záhorec - Hašková, JTIE, 2/2009, s. 69 -76), v ktorých boli prezentované niektoré výsledky široko koncipovaného výskumu zameraného na sledovanie možností ovplyvňovania postojov a vztahov študentov $k$ jednotlivým vyučovacím predmetom, a to hlavne $k$ tým, ktoré patria medzi ich neoblúbené predmety. V tomto príspevku autori predstavujú výsledky analýzy spol'ahlivosti/položiek dotazníka, ktorý bol použitý $v$ rámci uvedeného výskumu. Analýza spol'ahlivosti/položiek dotazníka bola použitá za účelom vytvorenia primeraného nástroja na získanie spol'ahlivých údajov na overenie možnosti ovplyvňovania vzt'ahu študentov $k$ vyučovacím predmetom pedagogickou intervenciou vytvorených elektronických učebných materiálov a interaktívnych animácií Základy geometrickej optiky do výchovno-vzdelávacieho procesu.
\end{abstract}

Kl'účové slová: multimediálny učebný materiál, dotazník, reliabilita, analýza spol’ahlivosti/položiek, Cronbachov koeficient alfa.

\section{1 Úvod}

V predchádzajúcom čísle časopisu sme prezentovali hlavnú čast' nami realizovaného výskumu overovania možností využívania multimédiami podporovaného vyučovania na elimináciu vysokej miery neobl'úbenosti určitých predmetov (Záhorec - Hašková, JTIE, 2/2009, s. 69 - 76). Nakol'ko ako výrazne neoblúbený predmet bola identifikovaná fyzika (Záhorec Hašková, JTIE, 1/2009, s. 83 - 91), sústredili sme sa na tento vyučovací predmet. Formulovali sme výskumnú hypotézu, v ktorej sme predpokladali, že vyučovanie podporované elektronickými výučbovými prostriedkami prispieva k znižovaniu negatívnych postojov $\mathrm{k}$ vyučovacím predmetom, konkrétne $\mathrm{k}$ vyučovaciemu predmetu fyzika. Na overenie stanovenej hypotézy bol použitý pedagogický experiment založený na pedagogickej intervencii nami vytvorených multimediálnych študijných produktov Základy geometrickej optiky. Na získanie relevantných výskumných údajov sme zostavili dotazník Zist'ovanie vzt'ahu a postojov študentov $\mathrm{k}$ vyučovaciemu predmetu fyzika, ktorý bol administrovaný respondentom výskumu (výskumná vzorka študentov štvrtého ročníka štvorročného a oktávy osemročného gymnázia) ako pretest pred začiatkom pedagogického experimentu a následne ako posttest po jeho ukončení. Účelom dotazníka bolo diagnostikovat' zmeny vo vzt'ahu študentov $\mathrm{k}$ sledovanému predmetu fyzika navodené uplatňovaním 
elektronickými výučbovými prostriedkami podporovaného vyučovania.

Názory respondentov v položkách dotazníka boli zaznamenávané na sedemstupňovej, resp. pät'stupňovej škále. Vyššia miera nesúhlasu s predloženým tvrdením (otázkou) bola označená nižšou hodnotou, úplný nesúhlas bol označený stupňom 1, vyššia miera súhlasu s predloženým tvrdením (otázkou) bola označená vyššou hodnotou, úplný súhlas bol označený stupňom 7 (resp. 5). U každého študenta bola pri spomínaných položkách $\mathrm{v}$ rámci pretestu ako aj $\mathrm{v}$ rámci posttestu zaznamenaná hodnota škály podl'a toho, akú mieru svojho súhlasu alebo nesúhlasu s jednotlivými tvrdeniami vyznačil. V jednotlivých položkách dotazníka študenti hodnotili fyziku z hl'adiska ich vlastného vzt’ahu $\mathrm{k}$ tomuto premetu, t.j. miery jej oblúbenosti, z hl'adiska zaujímavosti osvojovaných poznatkov, náročnosti osvojovaných poznatkov, zrozumitel'nosti výkladu nového učiva poskytovaného učitel'om, významu tohto predmetu pre všeobecné vzdelanie a život človeka. Okrem toho sme u každého študenta zaznamenali známku z fyziky na konci 3 . ročníka, ktorá predstavovala taktiež ordinálnu premennú.

$\mathrm{Na}$ analýzu spol’ahlivosti/položiek dotazníka sme použili techniky a metódy na posúdenie spol’ahlivosti dotazníka a identifikovanie jeho podozrivých položiek.

\section{Analýza spol'ahlivosti/položiek}

Analýza spol’ahlivosti/položiek patrí medzi viacrozmerné prieskumné techniky a slúži $\mathrm{k}$ posúdeniu kvality - spol’ahlivosti meracej procedúry, napríklad škály dotazníka a kidentifikovaniu podozrivých položiek. K priamym odhadom spol'ahlivosti patrí Cronbachov koeficient alfa

$$
\hat{\alpha}=\frac{m}{m-1} \cdot\left(1-\frac{\sum s_{j}^{2}}{s^{2}}\right)
$$

kde $m$ je počet položiek dotazníka, $s^{2}$ je rozptyl škály dotazníka, $s_{j}^{2}$ je rozptyl škály $\mathrm{j}$ - tej položky dotazníka.

Odhad reliability môžeme dostat' aj z priemerného korelačného koeficienta $\bar{r}$ jednotlivých položiek. Nazývame ho štandardizovaný Cronbachov koeficient alfa

$$
\bar{\alpha}=\frac{m \bar{r}}{1+(m-1) \bar{r}},
$$

kde $m$ je počet položiek.

Štandardizovaný Cronbachov koeficient alfa dostaneme aj z predchádzajúceho vzt'ahu, ak sme všetky merania dopredu štandardizovali, t. j. od každej hodnoty premennej sa odpočíta jej priemer a vydelí sa jej smerodajnou odchýlkou.

Ak sú obidva odhady príliš odlišné, indikuje to, že jednotlivé položky nemajú rovnakú variabilitu.

\section{Analýza spol’ahlivosti dotazníka}

$\mathrm{Na}$ analýzu spol'ahlivosti dotazníka sme použili techniky a metódy na posúdenie spol'ahlivosti dotazníka a identifikovanie jeho podozrivých položiek. Z korelačnej matice uvedenej v tabul'ke 1 môžeme identifikovat' jeho podozrivé položky. Zvýraznené korelačné koeficienty sú štatisticky významné na hladine významnosti 0,05 .

\begin{tabular}{|l|c|c|c|c|c|c|}
\hline & 1PRE & 2PRE & 3PRE & 4PRE & 5PRE & $\begin{array}{l}\text { Známka } \\
\mathbf{z} \text { fyziky }\end{array}$ \\
\hline 1PRE & 1,000000 & 0,601537 & 0,245188 & 0,447306 & 0,370703 & $-0,335337$ \\
\hline 2PRE & 0,601537 & 1,000000 & 0,099246 & 0,371584 & 0,485987 & $-0,167226$ \\
\hline 3PRE & 0,245188 & 0,099246 & 1,000000 & 0,314011 & 0,196405 & $-0,198659$ \\
\hline 4PRE & 0,447306 & 0,371584 & 0,314011 & 1,000000 & 0,282400 & $-0,335042$ \\
\hline 5PRE & 0,370703 & 0,485987 & 0,196405 & 0,282400 & 1,000000 & $-0,033369$ \\
\hline Známka z fyziky & $-0,335337$ & $-0,167226$ & $-0,198659$ & $-0,335042$ & $-0,033369$ & 1,000000 \\
\hline
\end{tabular}

Tabul'ka 1: Korelačná matica položiek pretestu. 
Z korelačnej matice tabul'ky 1 vidíme, že medzi väčšinou položiek sú korelácie štatisticky významné, čo znamená, že medzi týmito položkami existuje určitá miera vzájomnej závislosti. Čím viac sa korelačný koeficient približuje khodnote 1 , tým je priamoúmerná závislost' silnejšia. Výnimkou sú položky 2 a 3 , medzi ktorými nie je korelácia štatisticky významná, z čoho môžeme usúdit', že hodnoty sa menia nezávisle. Tieto položky sa na základe týchto výsledkov javia ako podozrivé.

Medzi položkou Známka z fyziky a všetkými ostatnými položkami je negatívna korelácia, t.j. hodnoty sa menia spoločne, ale $\mathrm{v}$ opačnom smere (kým hodnoty jednej premennej klesajú, druhej premennej rastú).

Korelačná matica jednotlivých položiek pretestu tabelovaná $\mathrm{v}$ tabul'ke 1 je graficky vizualizovaná na obr. 1 .

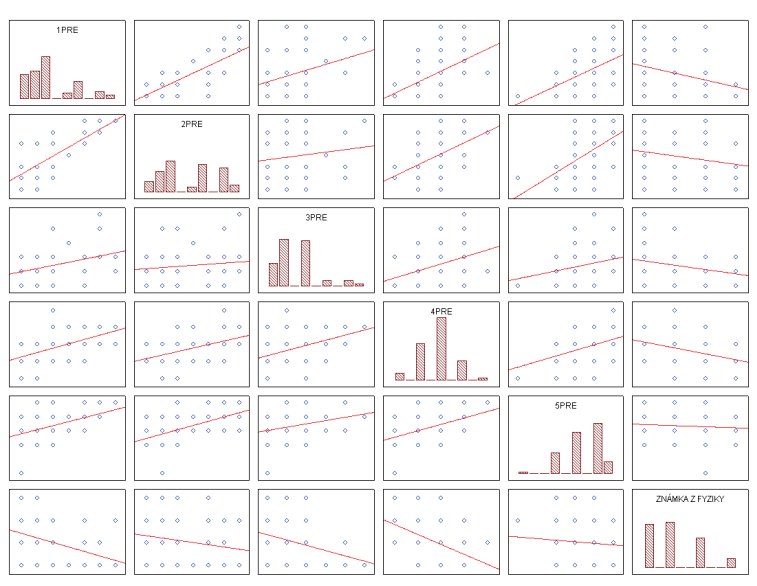

Obr. 1: Maticový graf-vizualizácia korelačnej matice (pretest).

\begin{tabular}{|l|c|l|c|}
\hline \multicolumn{2}{|l|}{ Počet položiek dotazníka: } & 5 \\
\hline Počet platn. prípadov: & 73 & 1207,0000000 \\
\hline Priemer: & 16,534246575 & Súčet & 21,835616438 \\
\hline Smerod. odch.: & 4,672859557 & Rozptyl & 28,000000000 \\
\hline Minimum: & 6,000000000 & Maximum & 0,782071554 \\
\hline Cronbachova alfa: & 0,767788059 & Standardiz. alfa & \\
\hline Priemerná korelácia medzi položkami: & 0,430876323 & \\
\hline
\end{tabular}

Tabul'ka 2: Súhrnné štatistiky dotazníka (pretest).

Hodnota koeficienta reliability 0,77 (77\%) vyjadruje podiel variability súčtu škály položiek k celkovej variabilite dotazníka. Obidva odhady (Cronbachova alfa a štandardizovaná alfa) nie sú príliš odlišné, t. j. jednotlivé položky majú rovnakú variabilitu (tabul'ka 2).

Dotazník môžeme považovat' za spol'ahlivý, avšak nízka priemerná korelácia medzi položkami naznačuje, že po odstránení niektorých položiek by sme mohli spol'ahlivost' dotazníka zvýšit'.

Z tabul'ky 3 vidíme, že všetky položky pretestu korelujú s celkovým skóre škály a po odstránení klesol koeficient reliability. U tretej položky sledujeme opačný stav, $\mathrm{v}$ tomto prípade koeficient reliability vzrástol. Po odstránení tretej položky sa zvýšil koeficient reliability Cronbachova alfa z 0,77 na 0,79 .

\begin{tabular}{|l|c|c|c|c|c|}
\hline & $\begin{array}{c}\text { Mean if } \\
\text { deleted }\end{array}$ & $\begin{array}{c}\text { Var. if } \\
\text { deleted }\end{array}$ & $\begin{array}{c}\text { StDv. if } \\
\text { deleted }\end{array}$ & $\begin{array}{c}\text { Itm.-Totl. } \\
\text { Correl. }\end{array}$ & $\begin{array}{c}\text { Alpha if } \\
\text { deleted }\end{array}$ \\
\hline IPRE & 13,54795 & 11,26140 & 3,355801 & 0,731071 & 0,646448 \\
\hline 2PRE & 12,58904 & 10,79002 & 3,284816 & 0,657158 & 0,692267 \\
\hline 3PRE & 14,09589 & 17,67574 & 4,204252 & 0,314200 & 0,789265 \\
\hline 4PRE & 13,75342 & 17,03509 & 4,127359 & 0,570327 & 0,735052 \\
\hline 5PRE & 12,15069 & 16,15538 & 4,019375 & 0,577968 & 0,723691 \\
\hline
\end{tabular}

Tabulka 3: Štatistiky dotazníka (pretest) po odstránení príslušnej položky.

Analýza spol'ahlivosti posttetu nám iba potvrdila výsledky analýzy spol’ahlivosti pretestu. Výsledky vo forme tabuliek a grafov sú uvedené v tabul'kách $4-6$ a na obrázku 2. 


\begin{tabular}{|c|c|c|c|c|c|c|}
\hline & 1POST & 2POST & 3POST & 4POST & 5POST & $\begin{array}{c}\text { ZNÁMKA } \\
\text { Z FYZIKY }\end{array}$ \\
\hline 1POST & 1,000000 & 0,630168 & 0,355395 & 0,391970 & 0,535228 & $-0,175595$ \\
\hline 2POST & 0,630168 & 1,000000 & 0,136654 & 0,292375 & 0,597861 & $-0,027205$ \\
\hline 3POST & 0,355395 & 0,136654 & 1,000000 & 0,392879 & 0,273538 & $-0,092467$ \\
\hline 4POST & 0,391970 & 0,292375 & 0,392879 & 1,000000 & 0,433043 & $-0,215245$ \\
\hline 5POST & 0,535228 & 0,597861 & 0,273538 & 0,433043 & 1,000000 & $-0,177702$ \\
\hline $\begin{array}{l}\text { ZNÁMKA } \\
\text { Z FYZIKY }\end{array}$ & $-0,175595$ & $-0,027205$ & $-0,092467$ & $-0,215245$ & $-0,177702$ & 1,000000 \\
\hline
\end{tabular}

Tabul'ka 4: Korelačná matica položiek posttestu.

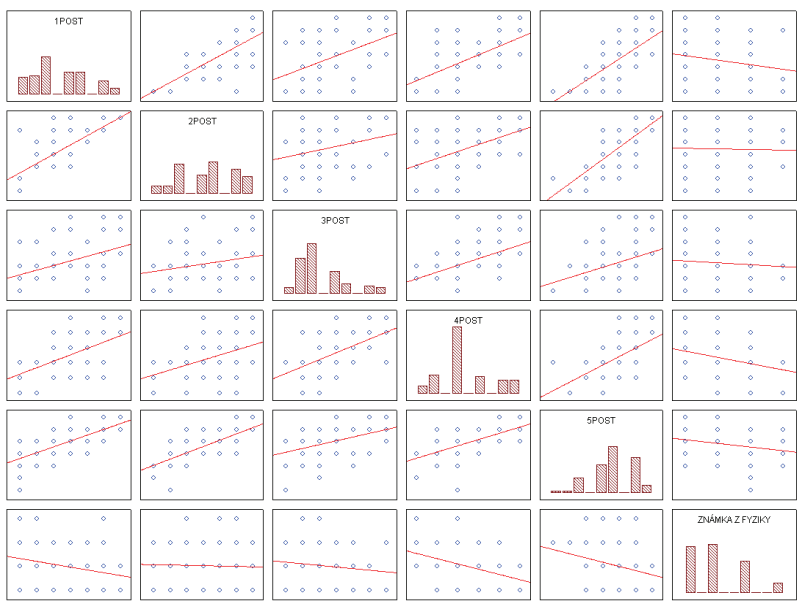

Obr. 2: Maticový graf-vizualizácia korelačnej matice (posttest).

\begin{tabular}{|l|c|l|c|}
\hline \multicolumn{2}{|l|}{ Počet položiek dotazníka: } & 5 \\
\hline Počet platn. prípadov: & 73 & 1425,0000000 \\
\hline Priemer: & 19,520547945 & Súčet & 32,169710807 \\
\hline Smerod. odch.: & 5,671834871 & Rozptyl & 34,000000000 \\
\hline Minimum: & 8,000000000 & Maximum & 0,843874534 \\
\hline Cronbachová alfa: & 0,840292399 & Standardiz. alfa & \\
\hline $\begin{array}{l}\text { Priemerná korelácia medzi } \\
\text { položkami: }\end{array}$ & 0,536805848 \\
\hline
\end{tabular}

Tab. 5: Súhrnné štatistiky dotazníka (posttest).

\begin{tabular}{|l|c|c|c|c|c|}
\hline & $\begin{array}{c}\text { Priem. po } \\
\text { odstr. }\end{array}$ & $\begin{array}{c}\text { Rozptyl po } \\
\text { ods. }\end{array}$ & $\begin{array}{c}\text { SmOdch } \\
\text { po ods. }\end{array}$ & $\begin{array}{c}\text { Pol-Celk } \\
\text { Korel. }\end{array}$ & $\begin{array}{c}\text { Alfa po } \\
\text { odstr. }\end{array}$ \\
\hline 1POST & 15,95890 & 18,20379 & 4,266590 & 0,781328 & 0,766232 \\
\hline 2POST & 15,05479 & 19,06549 & 4,366405 & 0,680823 & 0,799711 \\
\hline 3POST & 16,23288 & 23,68550 & 4,866775 & 0,451928 & 0,856600 \\
\hline 4POST & 16,16438 & 22,63051 & 4,757154 & 0,623301 & 0,814828 \\
\hline 5POST & 14,67123 & 22,00150 & 4,690576 & 0,735138 & 0,790543 \\
\hline
\end{tabular}

Tab. 6: Štatistiky posttestu po odstránení príslušnej položky.

\section{Záver}

Tret’ou položkou dotazníka, ktorá bola identifikovaná ako podozrivá a ktorej odstránenie viedlo k zvýšeniu spol'ahlivosti dotazníka, bola položka
Fyzika patrí medzi predmety...
a) vel'mi nenáročné
b) nenáročné
c) skôr nenáročné
d) ani náročné, ani nenáročné 
e) skôr náročné

f) náročné

g) vel'mi náročné

Touto položkou sme chceli získat' názor študentov na náročnost' vyučovacieho predmetu fyzika na gymnáziu. Pokladali sme ju za jednu z položiek, $\mathrm{v}$ ktorej respondenti vyjadria svoje jednoznačné stanovisko $\mathrm{k}$ náročnosti fyzikálneho obsahu vzdelávania stanoveného učebnými osnovami. Prostredníctvom štatistických metód sme však prišli k zaujímavým zisteniam. Meranie pomocou škály ukázalo, že patrila medzi položky, pri ktorých sa vyskytli najdivergujúcejšie odpovede a po jej odstránení sa najviac zvýšil koeficient reliability dotazníka. Táto položka znižovala spol'ahlivost' celého dotazníka z toho dôvodu, že aj študenti, ktorí na škále pri ostatných položkách vyjadrili súhlas s tým, že fyzika je pre nich skôr oblúbená, zaujímavá a významná, pri tejto položke súhlasili s hodnotením fyziky ako náročného predmetu. Takmer 2/3 respondentov $\mathrm{z}$ celého dátového súboru pedagogického experimentu volila možnost' e - skôr náročné, $f$ - náročné, alebo $g$ vel'mi náročné.

Aplikáciou prezentovanej analýzy sme získali spol'ahlivé experimentálne dáta, prostredníctvom ktorých sme mohli overit' hypotézu, že vyučovanie podporované elektronickými výučbovými prostriedkami prispieva $k$ znižovaniu negativnych postojov $k$ vyučovacím predmetom, konkrétne $k$ vyučovaciemu predmetu fyzika.

\section{Literatúra}

(1) ZÁHOREC, J. Elektronické výučbové prostriedky v technológii vzdelávania. Dizertačná práca. Nitra, PF UKF, 2008.
(2) ZÁHOREC, J. - HAŠKOVÁ, A. Hodnotenie stavu vyučovania informatiky a programovania z pohl'adu študentov. JTIE - Journal of Technology and Information Education, 2009, č. 1, s. 83 - 91. ISSN 1803-537X (print), ISSN 1803-6805 (on-line).

(3) ZÁHOREC, J. - HAŠKOVÁ, A. Empirický výskum ovplyvňovania vzt'ahu študentov $\mathrm{k}$ vyučovacím predmetom prostredníctvom multimediálnych učebných materiálov. JTIE Journal of Technology and Information Education, 2009, č. 2, s. $69-76$. ISSN 1803537X (print), ISSN 1803-6805 (on-line).

(4) ZÁHOREC, J. - MUNK, M. - HAŠKOVÁ, A. Case study of analysis of reliability/items of questionnaire. ICETA 2008. Košice: TUKE, 2008. s. 373 - 376. ISBN 978-80-8086-089-9.

Prof. PaedDr. Alena Hašková, CSc.

PaedDr. Ján Záhorec, PhD.

Ústav technológie vzdelávania

Pedagogická fakulta Univerzity Konštantína

Filozofa

Dražovská cesta 4, 94974 Nitra, SK

e-mail: ahaskova@ukf.sk, jzahorec@ukf.sk

RNDr. Michal Munk, PhD.

Katedra informatiky

Fakulta prírodných vied Univerzity

Konštantína Filozofa

Tr. A. Hlinku 1, 94974 Nitra, SK

e-mail: mmunk@ukf.sk

www.ukf.sk 